\title{
In vitro selection of ribozymes dependent on peptides for activity
}

\author{
MICHAEL P. ROBERTSON, ${ }^{1,3}$ SCOTT M. KNUDSEN, ${ }^{2,3}$ and ANDREW D. ELLINGTON ${ }^{2}$ \\ ${ }^{1}$ University of California-Santa Cruz, Santa Cruz, CA 95064, USA \\ ${ }^{2}$ Department of Chemistry and Biochemistry, Institute for Cellular and Molecular Biology, University of Texas at Austin, \\ Austin, Texas 78712, USA
}

\begin{abstract}
A peptide-dependent ribozyme ligase (aptazyme ligase) has been selected from a random sequence population based on the small L1 ligase. The aptazyme ligase is activated > 18,000-fold by its cognate peptide effector, the HIV-1 Rev arginine-rich motif (ARM), and specifically recognizes the Rev ARM relative to other peptides containing arginine-rich motifs. Moreover, the aptazyme ligase can preferentially recognize the Rev ARM in the context of the full-length HIV-1 Rev protein. The only cross-reactivity exhibited by the aptazyme is toward the Tat ARM. Reselection of peptide- and protein-dependent aptazymes from a partially randomized population yielded aptazymes that could readily discriminate against the Tat ARM. These results have important implications for the development of aptazymes that can be used in arrays for the detection and quantitation of multiple cellular proteins (proteome arrays).
\end{abstract}

Keywords: SELEX; aptazyme; aptamer; allosteric ribozyme; proteome

\section{INTRODUCTION}

Small, basic peptides have been shown to nonspecifically facilitate ribozyme catalysis. For example, basic peptide fragments from viral regulatory proteins such as the HIV-1 proteins Tat and Rev as well as the hepatitis delta virus (HDV) antigen have been shown to promote hammerhead ribozyme catalysis (Herschlag et al. 1994; Huang and Wu 1998). In the presence of an arginine-rich peptide from either the Rev or Tat protein, the rate of cleavage of an external substrate was increased up to threefold (Herschlag et al. 1994). Peptide fragments of the HDV delta antigen have also been shown to accelerate hammerhead cleavage ribozymes by up to 10 -fold in vitro. In both instances, the primary mechanism for peptide-assisted catalysis was the facilitation of RNA strand exchange and annealing. Similar effects were seen with nonnatural peptides that contained runs of lysine or arginine residues, and a tyrosine and an alanine on their $\mathrm{N}$ and $\mathrm{C}$ termini, respectively (Herschlag et al. 1994).

\footnotetext{
${ }^{3}$ These authors contributed equally to this work.

Reprint requests to: Andrew D. Ellington, Department of Chemistry and Biochemistry, Institute for Cellular and Molecular Biology, University of Texas at Austin, Austin, TX 78712, USA; andy.ellington@mail.utexas. edu.

Article and publication are at http://www.rnajournal.org/cgi/doi/ 10.1261/rna.5900204.
}

Although these examples show that peptides can facilitate ribozyme catalysis, the activations that were observed were surprisingly small. Methods have now been developed for the selection of effector-dependent ribozymes, or aptazymes, from random sequence pools (Koizumi et al. 1999; Wang et al. 2002), and the resultant effector activations have been extraordinary. A selected cGMP-dependent hammerhead variant was activated by 5000 -fold (Koizumi et al. 1999), and a tRNA synthetase-dependent L1 ligase variant was activated 94,000-fold (Robertson and Ellington 2001). Moreover, these ribozymes have proven to be quite specific for their effectors, and can discriminate between small molecules based on single hydroxyl moieties or between related protein effectors.

Thus, the kinetic characteristics of selected effector-dependent ribozymes seem to be qualitatively different than the kinetic characteristics of natural ribozymes augmented by basic peptides. This might be due to the fact that the basic peptides interact nonspecifically with natural ribozymes, whereas other effectors interact specifically with selected ribozymes. However, the same basic peptides that interact nonspecifically with natural ribozymes can also interact quite specifically with their cognate RNA molecules (Feng and Holland 1988; Lazinski et al. 1989; Olsen et al. 1990). For example, the arginine-rich motifs (ARMs) from BIV-1 Tat and HIV-1 Rev have been shown to form specific complexes with structured RNA molecules from these vi- 
ruses (Weeks et al. 1990; Kjems et al. 1992). Likewise, the ARMs of $\mathrm{N}$ proteins from bacteriophages $\lambda, \mathrm{P} 22$, and $\phi 21$ specifically interact with the boxB portions of their respective antiterminator elements (Lazinski et al. 1989). Further, nucleic acid binding species (aptamers) have been selected against a variety of protein and peptide ARMs, including HIV-1 Rev and Tat and HTLV-1 Rex, and all of these selected interactions have proven to be specific. A number of NMR solution structures of complexes between ARMs and their cognate RNA elements have been elucidated and reveal the molecular basis of recognition, including amino acid:nucleobase interactions and specific charge complementation (Patel 1999; Frankel 2000).

Based on these results, we hypothesized that it should be possible to select a ribozyme that would specifically interact with and be activated by a peptide. It would be particularly interesting to generate such ribozymes, as their mechanism of activation would be expected to differ substantially from nonspecific, facilitated annealing. In addition, peptide-dependent aptazymes could potentially be used as diagnostic or laboratory reagents (Frauendorf and Jaschke 2001). An advantage of aptazymes over conventional diagnostic reagents, such as antibodies, are that they can signal in homogenous solution without the need for multiple processing steps (Tang and Breaker 1997; Robertson and Ellington 2001). In addition, to the extent that peptide-dependent aptazymes could also recognize protein targets, in vitro selections that targeted peptide epitopes might prove to be a ready means for generating aptazymes against multiple protein targets. To determine whether and how peptides might specifically influence ribozyme catalysis, we have selected ribozyme ligases that are dependent on a peptide cofactor, the 17-mer ARM from the Rev protein of HIV-1. The Rev ARM was chosen because it has previously been shown to elicit aptamers and because interactions between the Rev ARM and a number of RNA ligands, both natural and unnatural, have been structurally characterized.

\section{RESULTS AND DISCUSSION}

\section{In vitro selection of peptide-dependent aptazymes}

We have previously selected protein-dependent aptazyme ligases from a random sequence pool based on the L1 ligase (Robertson and Ellington 2001). To generate peptide-dependent ligases, a similar protocol was developed (Fig. 1). The L1-N50 pool (Fig. 2) was incubated with a biotinylated substrate in the absence of peptide, and active ligases were removed from the population via streptavidin beads. The peptide effector and additional biotinylated substrate were then added, and active species were captured and selectively amplified by reverse transcription and PCR in the presence of a primer specific for the ligated substrate.

The peptide effector that was used during selection experiments was the ARM of HIV-1 Rev (Table 1), corre-

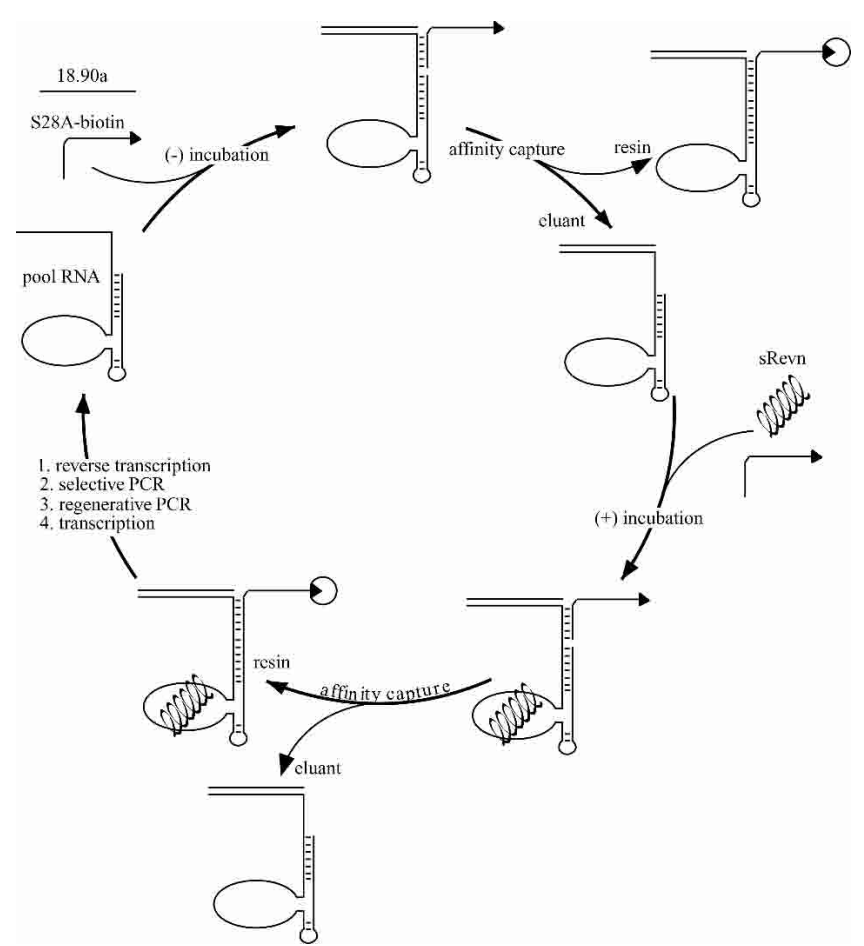

FIGURE 1. Selection scheme. Pool RNA (left) hybridized to a required DNA oligonucleotide (18.90a) was allowed to react with a biotinylated substrate (S28A-biotin) in the absence of effector, followed by capture and removal of active species, which were discarded. Peptide or protein effector and additional substrate were subsequently added to the reaction. Active species were captured, isolated, and amplified by reverse transcription and a selective PCR step. A regenerative PCR step created DNA templates from which a new pool, enriched in effector-activated species, could be transcribed for the next round.

sponding to amino acid residues 34-50 of the Rev protein. The 17-mer Rev ARM peptide assumes an alpha helical conformation in solution, and binds tightly $\left(K_{d} \sim 40 \mathrm{nM}\right.$ for sRevn; Tan et al. 1993) and specifically to the viral Revbinding element (RBE; Kjems et al. 1992; Tan et al. 1993). The Rev ARM peptide has also been used as a target for the in vitro selection of aptamers (Xu and Ellington 1996). The structures of the RBE, anti-Rev protein aptamers, and antiRev peptide aptamers in complex with the Rev ARM peptide have been solved by NMR (Battiste et al. 1996; Ye et al. 1996, 1999). This body of information and the resultant opportunities for comparative analyses made the Rev ARM peptide an excellent choice for aptazyme selection experiments. In particular, selected anti-Rev ARM peptide aptamers were found to bind to the Rev ARM in the context of the whole Rev protein (Xu and Ellington 1996). These results and others from the Frankel lab (Tan et al. 1993; Harada et al. 1997) are consistent with the hypothesis that the Rev ARM is either generally presented as an alpha helical epitope or is conformationally flexible enough that it can adapt to multiple peptide:RNA or protein:RNA interfaces. In either case, it was hoped that the use of the Rev ARM peptide as an effector would increase the probability that any se- 


\section{Robertson et al.}

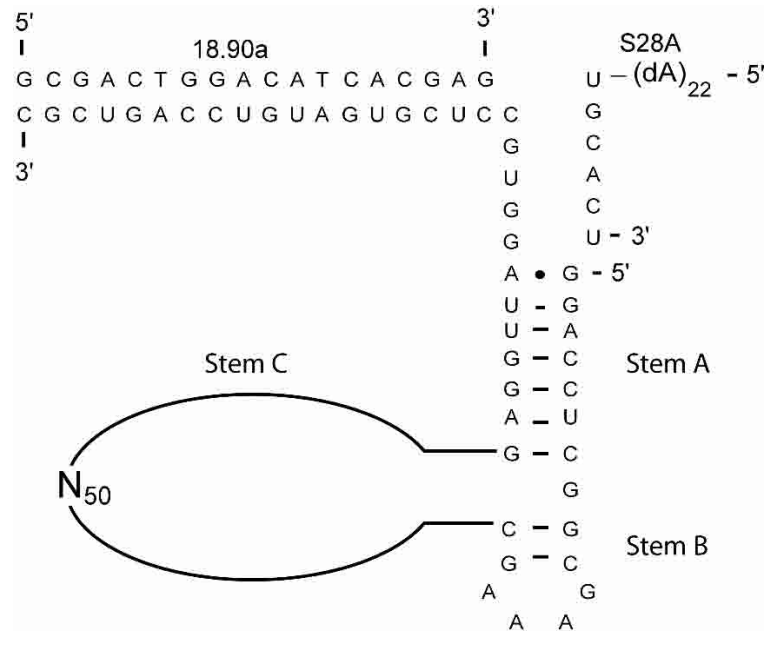

FIGURE 2. Pictographic representation of the L1-N50 pool used to select for peptide dependence. The RNA structure contains the L1 ligase stem $\mathrm{A}$ and a truncated stem $\mathrm{B}$; stem $\mathrm{C}$ has been replaced by a 50-nt random region $\left(\mathrm{N}_{50}\right)$. Also shown are the ribozyme substrate, S28A, and the DNA oligonucleotide 18.90a. The L1 ligase and its derivatives all require 18.90 a for activity.

lected peptide-dependent aptazymes would be cross-activated by the Rev protein.

The progress of the selection is shown in Figure 3. The stringency of the negative selection in the absence of the peptide effector was progressively increased by increasing the time allowed for ligation, from $24 \mathrm{~h}$ initially to $95 \mathrm{~h}$ by the conclusion of the selection. Conversely, the stringency of the positive selection in the presence of the peptide effector was increased by decreasing the time allowed for ligation, from $16 \mathrm{~h}$ at the start of the selection to $30 \mathrm{sec}$ at its conclusion. The degree to which a pool or individual clone was dependent on the peptide was termed "activation," defined as the rate of ligation in the presence of peptide divided by the rate in the absence of peptide.

After seven rounds of selection and amplification, the pool showed very modest dependence on the Rev ARM peptide. A more thorough kinetic analysis of the ligation rate of the population in the presence of the peptide effector yielded a biphasic curve (data not shown). The faster ligation rate corresponded to the ligation rate of the population in the absence of the peptide effector. The simplest explanation for this data was that the population contained both fast, peptide-independent ribozymes and at least some Rev ARM peptide-dependent ribozymes that were on average 60-fold slower than the peptide-independent catalysts. Further selection did not improve the activation parameters of the population.

\section{Sequence and activity of a peptide-dependent aptazyme}

The Round 7, 8, and 9 populations were cloned and sequenced, and individual variants were assayed for ligation in the presence and absence of the Rev ARM peptide (Fig. 4). As expected, most of the individual sequences were not Rev ARM peptide dependent. Instead, there were multiple, apparently inactive variants, and two copies of a highly active variant (8-1) that was nearly identical to a previously isolated ribozyme, JH-1 (Robertson et al. 2001) except for a single point mutation (G40A) that converted a U:G wobble to a U:A base pair. Only one Rev ARM peptide-dependent aptazyme (8-4) was identified.

The accumulation of inactive variants has not been observed during previous selections for ligase activity. With the exception of variants 8-1 and 8-4, the remaining variants showed no ligation activity not only under standard ligation assay conditions, but also in the context of a mock selection reaction (see Materials and Methods). Nonetheless, the accumulation of multiple (11) copies of variant 8-2 seemed to indicate that it enjoyed some selective advantage relative to the remainder of the population. Additional ligation assays were carried out with variant 8-2 in the presence of other factors present during the selection, including biotinylated substrate, streptavidin-agarose beads, nonlabeled pool RNA, and reverse transcriptase. However, no ligase activity was ever observed (data not shown). It is possible that 8-2 and other variants represent replication parasites (Green et al. 1990), sequences that have discovered a mechanism that allows them to preferentially replicate without undergoing ligation. For example, replication parasites that preyed upon isothermal amplification conditions arose during selections for nucleic acid binding species (aptamers), as opposed to nucleic acid catalysts (Marshall and Ellington 1999). Although the origin of 8-2 is being further explored, the fact that a population selected for Rev ARM peptide-dependent function was overrun by both inactive and Rev-independent variants indicates that Rev ARM peptide-dependent aptazymes may be relatively rare.

The one Rev ARM peptide-dependent variant that was obtained, aptazyme 8-4, was characterized in greater detail (Fig. 5). At the concentration of Rev ARM peptide used during the selection $(10 \mu \mathrm{M})$ aptazyme $8-4$ was activated by $>18,000$-fold. Under these assay conditions,--aptazyme 8-4 had a ligation rate of $1.2 \mathrm{~h}^{-1}$, similar to the parental L1 ligase $\left(0.71 \mathrm{~h}^{-1}\right)$ under optimal buffer conditions (Robertson and Ellington 1999). The fact that the aptazyme did not have a greatly improved rate relative to the parental ribozyme is consistent with the mechanism of catalysis remaining dependent only on RNA, and independent of the peptide effector.

The ligation of aptazyme 8-4 was also examined as a function of increasing Rev ARM peptide concentration (Fig. 5C). Although aptazyme function was initially titrated by the Rev ARM peptide, at concentrations $>5 \mu \mathrm{M}$ the peptide proved to be increasingly inhibitory. We suspected that the multiple arginine residues in the ARM might compete for critical magnesium-binding sites on the aptazyme, just as aminoglycosides have been shown to compete for magne- 
TABLE 1. Peptide sequences

\begin{tabular}{cll}
\hline Number & \multicolumn{1}{c}{ ARM protein } & \multicolumn{1}{c}{ Peptide sequence } \\
\hline 1 & HIV-1 Rev & TRQARRNRRRRWRERQR \\
2 & HIV-1 Tat & SYGRKKRRQRRRPPQ \\
3 & BIV Tat & SGPRPRGTRGKGRRIRR \\
4 & HTLV-1 Rex & MPKTRRRPRRSQRKRP \\
5 & HIV-1 Rev (N7D) & TRQARRDRRRRWRERQR \\
6 & HIV-1 Rev (R11Q) & TRQARRNRRRQWRERQR \\
7 & HIV-1 Rev (R10Y) & TRQARRNRRYRWRERQR \\
8 & N N & MDAQTRRRERRAEKQAQWKAAN \\
9 & P22 N & NAKTRRHERRRKLAIER \\
10 & \$21 N & TAKTRYKARRAELIAERR \\
11 & BMV Gag & KMTRAQRRAAARRNRWTAR \\
12 & CCMV Gag & KLTRAQRRAAARKNKRNTR \\
13 & PRP6 & TRRNKRNRIQEQLNRK \\
14 & U2AF & SQMTRQARRLYV \\
15 & RNA Pol sigma factor & GAAARRHLLEANLRLVV \\
16 & Ribosomal protein L20 & DRRARKGEFRKLWISR \\
\hline
\end{tabular}

The sequences of peptides used for selection and assay are tabulated. Bold typeface indicates altered positions in the Rev ARM peptide sequences. factor of two; additional suppression of ligase activity was observed when the $\mathrm{KCl}$ concentration was further increased. At $1 \mathrm{M} \mathrm{KCl}$, ligation rates were $>10$-fold lower than in the normal buffer. A similar trend has been previously observed with another selected aptazyme; a lysozyme-activated clone Lys 11-2 that was previously described (Robertson and Ellington 2001) has also been shown to be inhibited by increased monovalent salt concentration (see Robertson and Ellington 2001; supplementary material).

Because the L1-N50 pool was derived from the catalytic core of the L1 ligase, it is likely that aptayzme 8-4 retained much of the L1 ligase structure. In fact, the 8-4 sequence is predicted to form a secondary structure (Mathews et al. 1999) that overlaps with the previously determined L1 ligase secondary structure (Fig. 6). Experimental evidence also supports the congruence of the structures. The sium-binding sites on other ribozymes (Rogers et al. 1996). However, when the activity of the aptazyme was examined as a function of both magnesium and peptide concentration, there was no rescue of ligation activity by magnesium (data not shown). Instead, there was a general inhibition of ligation activity at high peptide $(>5 \mu \mathrm{M})$ and/or magnesium $(100 \mathrm{mM})$ concentrations. The simplest explanation for these results is that the ligase is inhibited at high ionic strengths. This hypothesis was further supported by the fact that ligase activity also decreased when additional monovalent salt was added to the buffer. An additional $50 \mathrm{mM} \mathrm{KCl}$ (to $150 \mathrm{mM} \mathrm{KCl}$, total) was sufficient to reduce the ligation rate in the presence of the Rev ARM peptide by nearly a

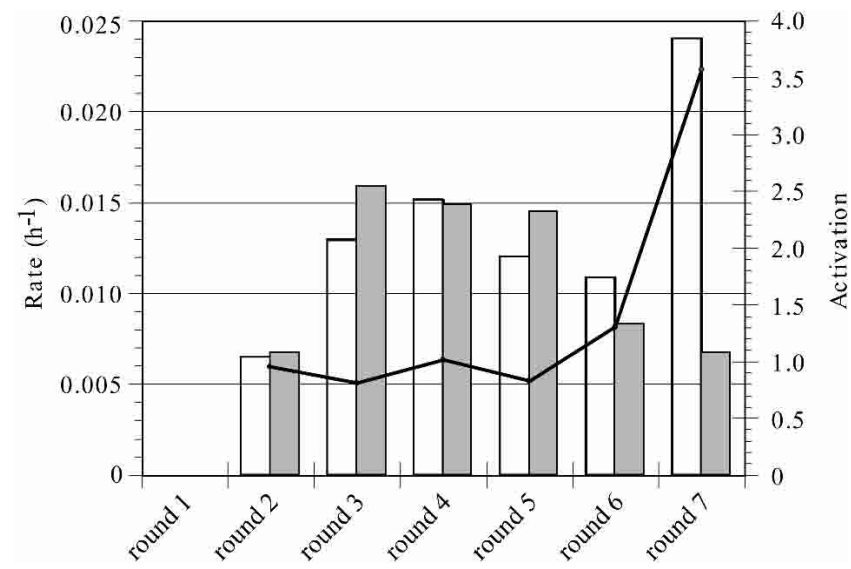

FIGURE 3. Selection for Rev ARM dependence. The progress of the selection is shown for Rounds 1-7. Ligation rates in the presence and absence of the peptide effector are plotted on the left $y$-axis with white and gray bars, respectively. Activation (ligation rate with peptide/ ligation rate without peptide) for each round is represented as a line whose underlying values correspond to the right $y$-axis.
L1 ligase is known to be dependent on a hybridizing oligonucleotide (18.90a) for activity (Robertson and Ellington 1999); aptazyme 8-4 was also found to be dependent upon this oligonucleotide for activity. Additionally, mutations that arose during reselection experiments support the proposed secondary structure, as discussed below.

Previous selections for protein-dependent aptazymes (Robertson and Ellington 2001) have also yielded secondary structures that retained the three stem junction found in the parental L1 ligase; for example the CYT-18 dependent clone L1-cyt 7-2 (Fig. 6). Just as the protein-dependent aptazymes did not closely resemble known antiprotein aptamers, aptazyme 8-4 does not closely resemble natural or selected sequences or secondary structures that are known to bind either the HIV-1 Rev ARM peptide or the Rev protein. The lack of correspondence between aptazyme allosteric sites and aptamer binding sites is not surprising, because the transduction of binding energy into a ribozyme conformation that supports catalysis likely requires a quite different set of peptide:nucleic acid interactions than would be required for binding alone.

\section{Specificity of a peptide-dependent aptazyme}

The specificity of aptazyme 8-4 for its peptide effector was determined by assessing the ability of a variety of argininerich peptides (Table 1) to activate the ribozyme. Peptides that were closely related to the Rev ARM peptide could generally activate catalysis. The peptide originally used for selection was sRevn, which is succinylated at its amino terminus and amidated at its carboxy terminus. The aptazyme was even more strongly activated by aRev, which is acetylated at its amino terminus. Activation could also be induced to varying degrees by Rev ARM peptides containing 


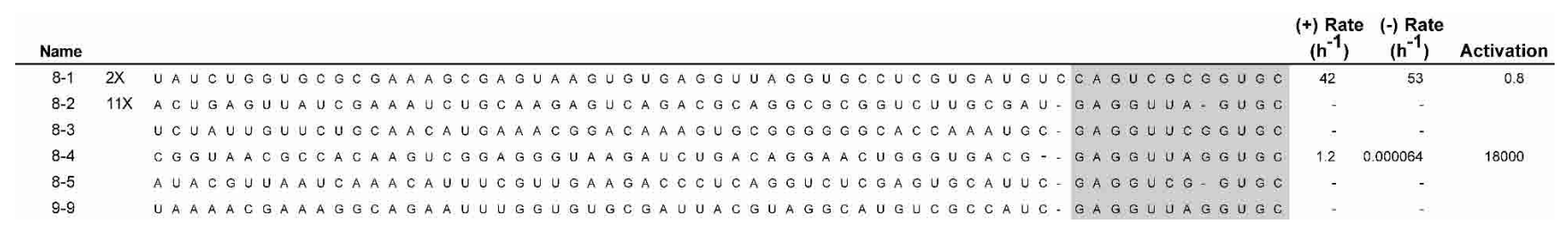

FIGURE 4. Sequences from the selection for Rev ARM dependence. The sequences of variants are shown on the left. The shaded region indicates the $3^{\prime}$ constant region that contributes to stem A. Ligation rates in a standard assay are shown on the right in the presence $(+)$ and absence $(-)$ of the Rev ARM peptide. No listed rate indicates that the observed rate was $<0.003 \mathrm{~h}^{-1}$.

single amino acid substitutions, including Rev N7D, Rev R10Y, and Rev R11Q (for simplicity, numbering is according to position in the peptide, not the original Rev protein), although activation was less than that observed with the wild-type Rev ARM peptide (sRevn). These substitutions were chosen because the individual amino acids had previ-

A

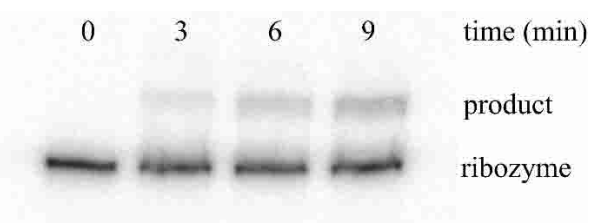

B

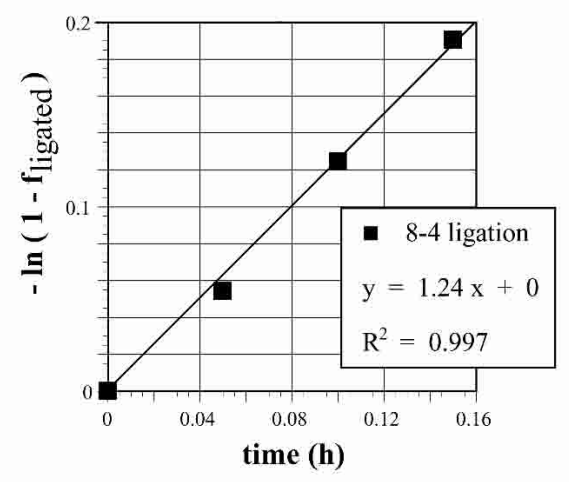

C

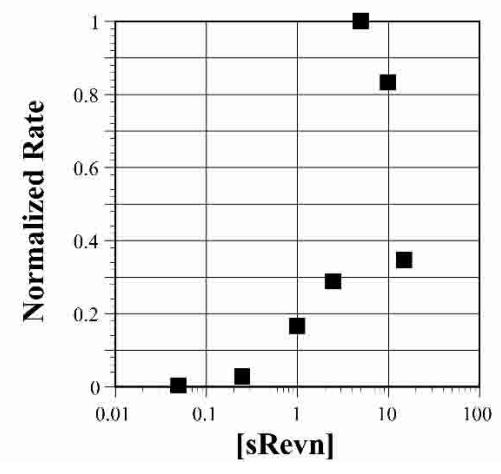

FIGURE 5. Measuring ligation activity. (A) A standard ligation assay for aptazyme 8-4 in the presence of sRevn $(10 \mu \mathrm{M})$ is shown. (B) Data derived from $a$ and linearized fits the displayed equation. $(C)$ The effect of peptide concentration on the ligation rate of aptazyme 8-4. ously been shown to make base-specific contacts with either the natural Rev-binding element or with a selected anti-Rev aptamer (Peterson and Feigon 1996; Ye et al. 1996; Fig. 11B, see below). The aptazyme was not activated by truncated, half-fragments of the Rev ARM (Rev 1-9; Rev 10-17), nor was it activated by arginine alone, even when arginine was introduced at a concentration 10 -fold greater than that used for peptide effectors. Taken together, these results indicate that the 8-4 aptazyme recognizes a number of individual features of the Rev ARM peptide, just as previously selected aptamers have been found to bind residues throughout various ARMs (Battiste et al. 1996; Jiang et al. 1999; Ye et al. 1999; Gosser et al. 2001).

Aptazyme 8-4 showed little or no activation by a variety of unrelated ARM peptides (Fig. 7) or proteins. The specificity of the 8-4 aptazyme was quite remarkable, considering that the overall charge on the other peptides ranged from +2 to +9 at neutral $\mathrm{pH}$ (the Rev ARM peptide itself had a net charge of +9 ). Even though these peptides should show considerable nonspecific binding to many RNA molecules, including the 8-4 aptazyme, specific interactions with the Rev ARM peptide are apparently required for aptazyme activation. Again, these results are reminiscent of those obtained with protein-dependent aptazymes (Robertson and Ellington 2001).

An exception to the apparent effector specificity of aptazyme 8-4 was the fact that a Tat ARM peptide reproducibly induced $\sim 5000$-fold activation. This was especially surprising as there is no known sequence or structural relationship between the Tat ARM and the Rev ARM. One notable similarity is that the Rev and Tat ARMs both have three or more consecutive arginine residues, and it may be that this feature leads, in part, to the activation of aptazyme 8-4. In keeping with this interpretation, the substitution R10Y in the Rev ARM breaks up four consecutive arginine residues, and was the amino acid substitution that had the largest effect on activation; other substitutions in this run of arginine residues were also found to greatly affect activation (Fig. 11A, see below). However, the presence of a run of arginines was not sufficient to ensure aptazyme activation, because both the lambda N and P22 N proteins also contained three consecutive arginine residues, yet showed no ability to activate aptazyme $8-4$.

Most importantly, the HIV-1 Rev protein also proved 

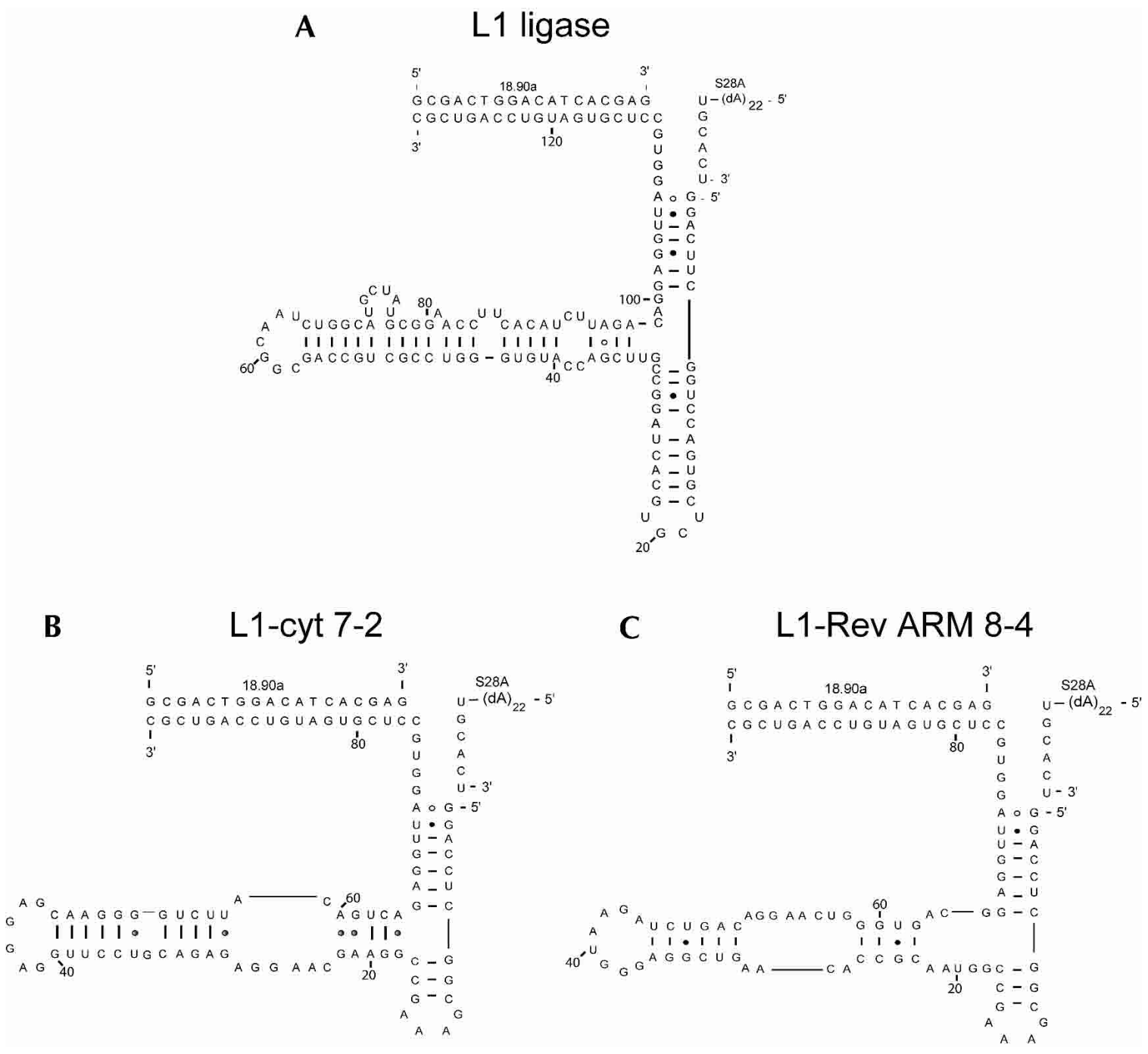

FIGURE 6. Predicted L1 ligase structures. (A) The predicted structure of the original L1 ligase. (B) The predicted structure of L1-cyt 7-2. (C) The predicted structure of the Rev ARM-dependent aptazyme 8-4.

capable of activating the Rev ARM-dependent aptazyme, although the level of activation was small $(\sim 3500$-fold $)$ compared to the peptide effector (Fig. 7). In contrast to the results with peptide effectors, the 8-4 aptazyme was not activated by the Tat protein or by other protein effectors that did not contain ARMs.

\section{Reselection of peptide- and protein-dependent aptazymes}

Because aptazyme 8-4 was the only Rev-dependent sequence that was identified, it was impossible to discern by comparative analyses what sequence or structural motifs were important for function. Moreover, aptazyme variants might show even greater specificity for the Rev ARM peptide or Rev protein. Therefore, a second set of selection experiments was carried out starting from a doped sequence library centered on 8-4. Each residue in the original random sequence region was randomized such that $70 \%$ of the residues were wild type, and $30 \%$ were non-wild type (i.e., $70 \%$ G, 10\% A, 10\% U, and 10\% C). Peptide-dependent aptazymes were selected from the doped sequence population in the same way that they were selected from the original random sequence population. In addition, a second selection was carried out in which the doped sequence pool was selected using the whole Rev protein as the effector, rather than the Rev ARM peptide.

The peptide dependence of the doped pool progressively increased over four rounds of selection and amplification (Fig. 8A). However, the peptide dependence dropped sharply in later rounds, again due to the appearance of extremely active ribozymes (the 8-1 variant) that no longer relied on the peptide for activity. Aptazymes from Rounds 4,5 , and 6 were cloned, sequenced, and assayed for their 


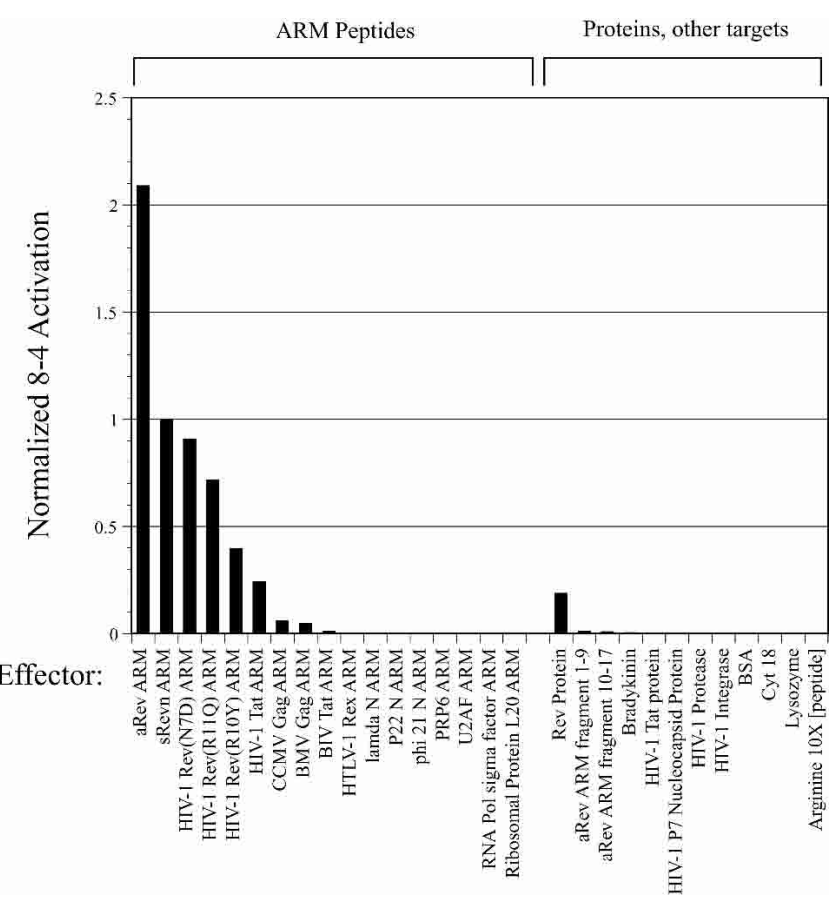

FIGURE 7. Specificity of aptazyme 8-4 for the Rev ARM. The rate of 8-4 ligation in the presence of the Rev ARM is shown relative to the rate of ligation in the presence of similar ARMs and various proteins and other effectors. Activation values have been normalized to the activation value observed with sRevn, the peptide effector used throughout the selection.

peptide dependence (Fig. 9A). On average, there were four to five mutations per selected variant. Although there was an accretion of relatively peptide-independent ribozymes in later rounds, there were still numerous peptide-dependent aptazymes in the population, some of which showed better activation than the original aptazyme 8-4. For example, variant 4 f was activated by 38,000 -fold by the Rev ARM peptide, $>2$-fold better than the parental aptazyme. The best aptazymes generally had increased ligation rates in the presence of the peptide effector, rather than decreased ligation rates in the absence of the peptide.

A

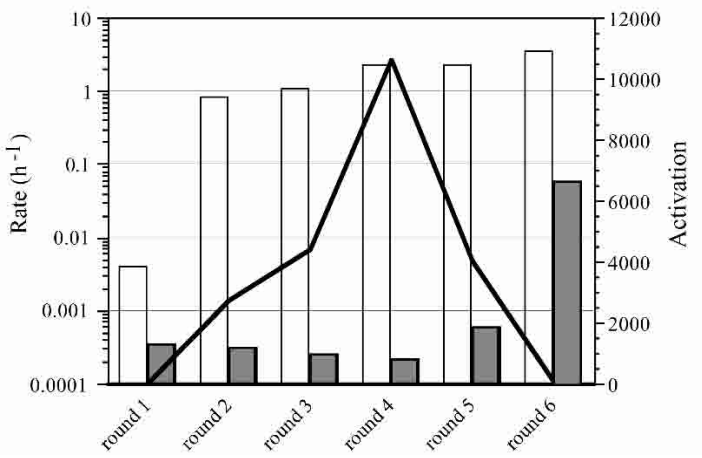

Even though there were several aptazyme variants that should have had a selective advantage over the parental aptazyme, sequences identical to 8-4 were isolated numerous (18) times. It is possible that the parental aptazyme somehow contaminated the reselection experiment. However, given the fact that the consensus sequence identified by reselection is identical to $8-4$, it is also reasonable to assume that the numerous parental sequences (an estimated $25,000,000$ based on a $30 \%$ doped population) that were present in the doped sequence pool were carried through to the conclusion of the selection.

Similar trends were observed during reselection for dependence on the Rev protein. Selection was carried out over six successive rounds (Fig. 8B). In the last round there was again an increase in ligation rates in the absence of the protein effector, resulting in poorer overall activation. Aptazymes from Rounds 5 and 6 were cloned, sequenced, and assayed for their protein dependence (Fig. 9B). On average, there were six to seven mutations per selected variant. Ligation rates and overall activation parameters of these aptazymes in the presence of the protein effector were generally less than those of their peptide-dependent counterparts. For example, the fastest peptide-dependent aptazyme (4h) had a rate of $3 \mathrm{~h}^{-1}$ in the presence of peptide, whereas the fastest protein-dependent aptazymes $(6 \mathrm{c}, 6 \mathrm{n})$ had a rate of only $0.3 \mathrm{~h}^{-1}$ in the presence of protein. Moreover, only one variant was isolated $(6 \mathrm{k})$ whose protein-dependent activation (3,900-fold) was on par with the parental 8-4 ribozyme (3,500-fold). The consensus sequence identified by reselection for protein dependence again closely corresponded to the parental aptazyme (Fig. 9B), although in this instance none of the reselected aptazymes was identical to $8-4$.

Residues important for aptazyme activity and activation could be identified by observing which positions varied significantly less than the originally programmed $30 \%$ upon reselection. Eighteen of the 49 randomized residues were invariant following reselection with the peptide effector, whereas 21 were invariant following reselection with the

B

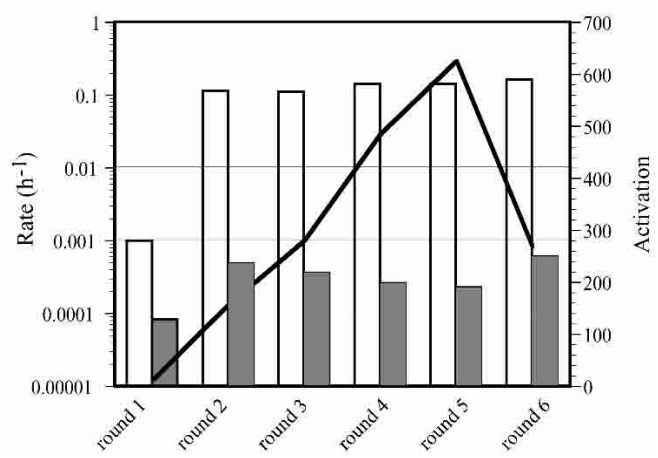

FIGURE 8. Reselection for Rev ARM and Rev protein dependence. The progress of the selections is shown for $(A)$ peptide and $(B)$ protein dependence. Data is represented as in Figure 3. 

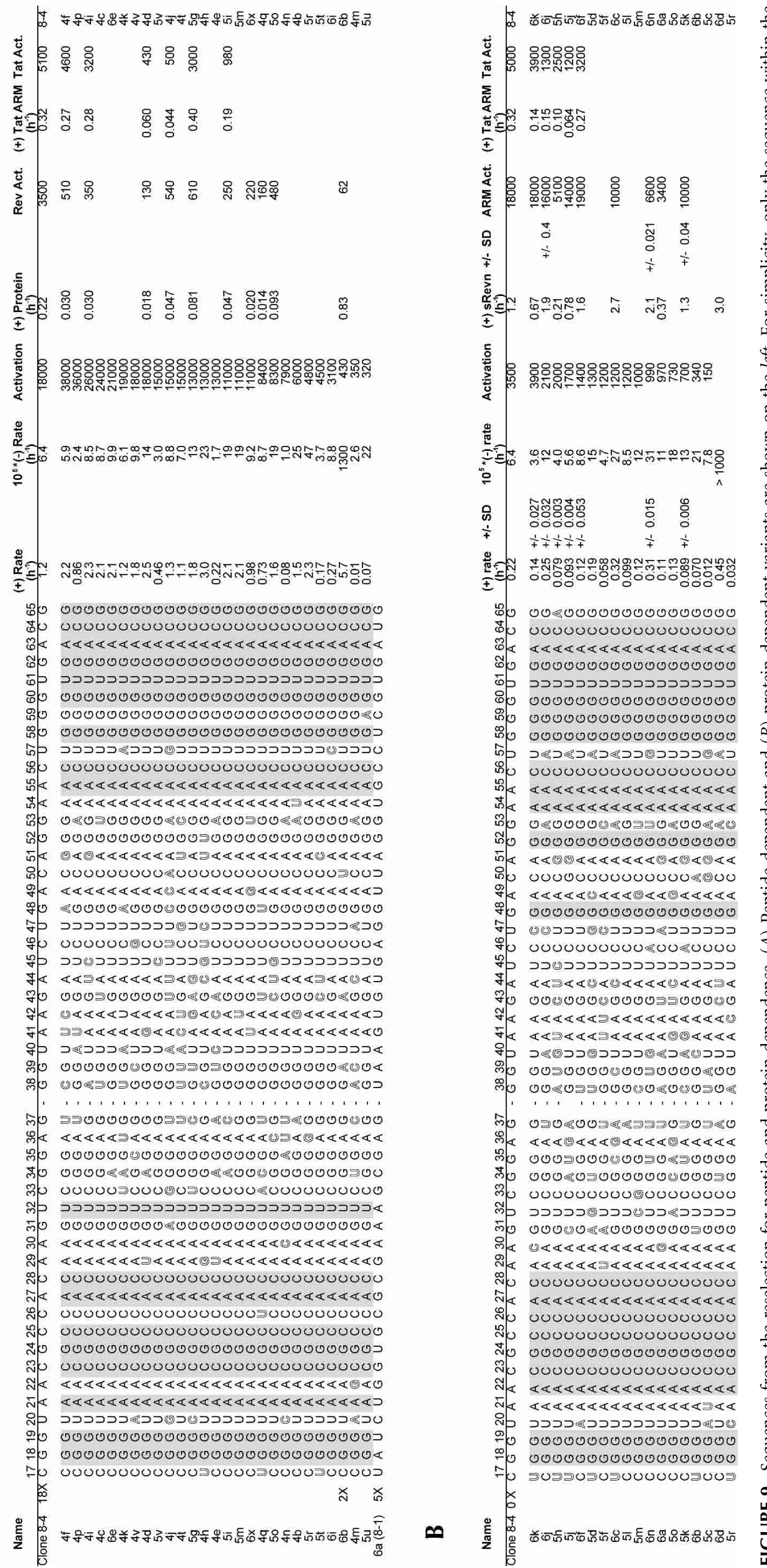

$\stackrel{ \pm}{\frac{5}{5}}$

站

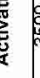

要

$\stackrel{\circ}{\circ}$

\section{$\frac{5}{4}$}

密的

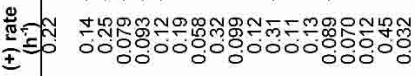

\$0 00\$000000000000000

कै. 000000000000000000

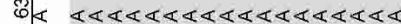

ब0 000000000000000000

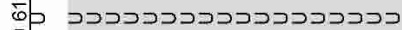

80 000000000000000000

if 000000000000000000

î

in

is 000000000000000000

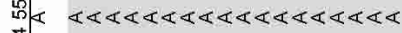

品质

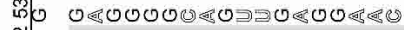

No 000000000000000000

的《 $\varangle<$ (ख)

if $00000000000000 \times 000$

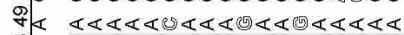

go 000000000000000000

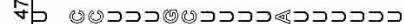

if 0000000000 \&00ख0

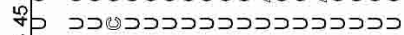

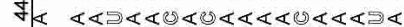

Fo $00000000000 D 500000$

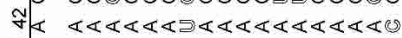

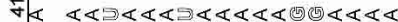

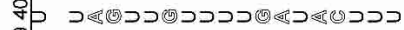

if 00D0000000כ0000ख्य०

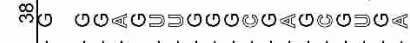

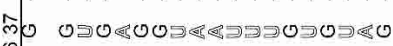

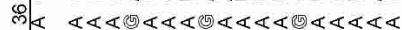

no $000500000050<50000$

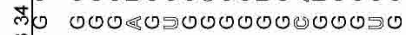

\%) 00000000000000000

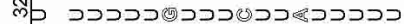

no 00000 死 00000005000

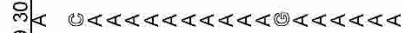

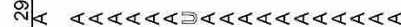

जै 000000000000000000

N

if 000000000000000000

Nif 000000000000000000

\$f 000000000000000000

ती 000000000000000000

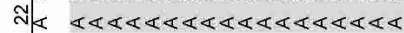

的金

הט

S0 000000000000000000

की 000000000000000000

fo 509505090000005009

a

空

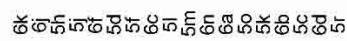

它.

造。

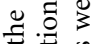

5.

글

हैं

的寻

ㅎํ

苾

클 栗

ॠ

苛产

चี

प्षे के

$\Xi$

융

要

نี

ए

$\Xi \Xi$

क्षे

렁

乎

잉

记

ส 3 ฮ

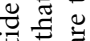

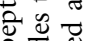

ฉ.

훙

흘

远

巴㔾

里

둥

$\circ .0$

可

:

巳 릉

छั ซ

क ज

$\sigma$.

山之르 


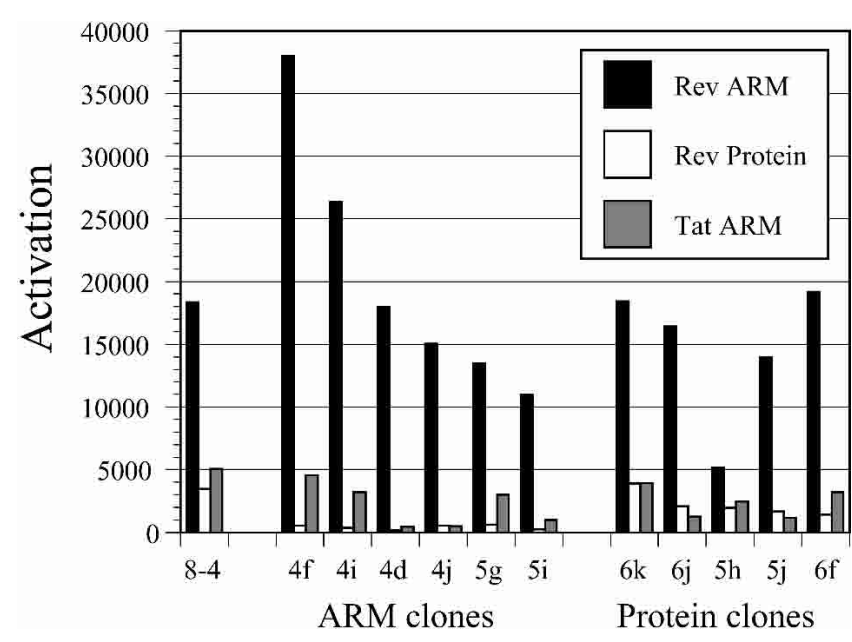

FIGURE 10. Specificities of selected variants. Activation data from Figure 9 is replotted as a bar graph.

protein effector. By and large, the residues that were important for peptide activation overlapped with those that were important for protein activation. Interestingly, there were also a number of residues that appeared to be positively selected for improved ribozyme activity or effector dependence. As a measure of the significance of a given change, we can calculate $P$, the probability that said occurrence would arise by chance in the doped pool. For example, G37U was selected in $30 \%$ of variants $(P=0.00011)$, whereas a G53A mutation was found in $24 \%$ of selected variants $(P=0.0048)$. Additionally, there were two mutations that were found in only a few of the ARM-dependent variants, but which appeared more widely during the selection for protein dependence. The $\mathrm{C} 17 \mathrm{U}$ mutation was found in 39\% of variants isolated for protein dependence $(P=0.0012)$ and an A51G mutation was found in $28 \%$ of variants $(P=0.028)$. At other positions, residues were apparently functionally neutral, in that they varied at rates close to 30\%; specifically, positions G34, G38, A42, G43, and A44 among the Rev ARM peptide-dependent variants showed an average of $25 \%$ variation, whereas positions $\mathrm{G} 35$, G38, U40, G43, A44, U47, and U57 among the Rev proteindependent variants showed an average of $34 \%$ variation.

As mentioned above, reselected sequences also provided support for the secondary structural model of 8-4 (Fig. 6). The sequence change G37U appeared in 14 of 46 reselected variants $(P=0.00011)$. This substitution would introduce an additional U:A base pair at the end of the proposed stem C. The sequence change G34A appeared in six reselected variants and would convert a proposed G:U wobble pair to an A:U base pair.

\section{Specificities of reselected aptazymes}

One of the most intriguing results from the initial selection was that aptazyme 8-4 was activated by the unrelated Tat
ARM. To determine whether and how the specificities of reselected aptazymes may have changed, aptazyme variants were assayed with the Rev ARM peptide, the Rev protein, and the Tat ARM as effectors (Fig. 10). A number of specificity changes between the wild-type aptazyme 8-4 and its selected progeny were immediately apparent. In general, aptazymes selected for peptide activation showed poor protein activation, much poorer than either aptazyme 8-4 or the aptazymes that were selected for protein activation. For example, all of the reselected Rev ARM peptide-dependent aptazymes assayed were activated 600 -fold or less by the Rev protein, whereas aptazyme 8-4 and most of the reselected protein-dependent aptazymes that were assayed showed greater than 600 -fold dependence on the Rev protein. In contrast, aptazymes selected for protein activation still showed excellent Rev ARM peptide activation. Most importantly, several of the aptazymes selected against both the Rev ARM peptide and the Rev protein showed improved discrimination against the Tat ARM peptide. In particular, whereas the wild-type aptazyme 8-4 discriminates against the Tat ARM by only a factor of 3.6-fold, the reselected aptazyme $4 \mathrm{~d}$ discriminates against the Tat ARM by a factor of 41 -fold, and aptazyme $4 \mathrm{j}$ discriminates against the Tat ARM by a factor of 30 -fold. Remarkably, aptazyme $4 \mathrm{~d}$ differs from the wild-type aptazyme 8-4 by only three nucleotide substitutions.

\section{Aptazyme recognition of individual amino acids}

Although 8-4 and its derivatives appear to be largely specific for their cognate effectors, it was unclear whether individual amino acids within the Rev ARM peptide specifically contributed to activation, or whether activation was due to general charge complementation, as might be the case if the Rev ARM were serving as a nonspecific mediator of secondary structural rearrangements or substrate annealing. To address this problem, a series of peptides was created wherein each successive residue was replaced by an alanine, and the abilities of these peptides to activate clones 8-4, 4d, and $4 \mathrm{f}$ were determined in a standard assay (Fig. 11A). The helicities of a similar series of peptides has been previously characterized by circular dichroism (Tan et al. 1993). All of the peptide variants were found to have a helical content that was similar to that of the wild-type Rev ARM. Therefore, individual alanine substitutions should not have dramatically affected the overall structure of the peptide. For each clone, the activity in the presence of each of the alanine-scan peptides has been normalized to its activity in the presence of the wild-type Rev ARM (shown as the fourth peptide in the series, because this position is normally an alanine).

The most dramatic effect on activation was seen upon substitution of either R5, R8, or R9, each of which led to a loss in activation of an order of magnitude or more. Substitutions at other positions also modulated both increases 
A

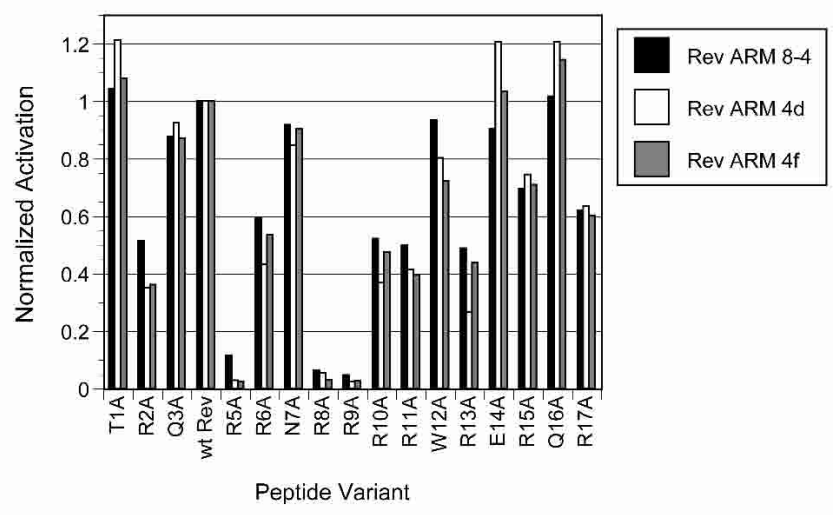

B

TR Q A R R N R R R W R E R R Rev-ARM Dependent Clones $\underline{\underline{R}} \underline{\mathrm{Q}} \underline{\mathrm{A}} \underline{\mathrm{R}} \underline{\mathrm{R}} \underline{\mathbb{N}} \underline{\mathrm{R}} \underline{\mathrm{R}} \underline{\mathrm{R}} \underline{\mathrm{R}} \underline{\mathrm{W}} \underline{\mathrm{R}} \mathrm{E} \underline{\mathrm{R}} \mathrm{Q} \underline{\mathrm{R}} \quad \operatorname{RBE}(\mathrm{RRE}$ Stem IIB) TRQ A RR N $\underline{R} R R \underline{R} \underline{\text { R }} E R Q R$ Anti-Peptide Aptamer $\underline{T} \underline{R} Q \mathbf{Q} \underline{R} \underline{R} \underline{N} \underline{R} \underline{R} \underline{R} \underline{R} W \underline{R} \in \underline{R} Q \underline{R}$ Anti-Protein Aptamer

FIGURE 11. Functional importance of individual amino acids. $(A)$ Aptazyme activation. Each amino acid in the Rev ARM was individually substituted with alanine, and each alanine-substituted peptide was assayed for its ability to activate selected ribozyme clones. Activation by a given variant is plotted relative to activation by the wild-type peptide, which is the fourth peptide in the series. Data is plotted as in Figure 7. (B) Rev-ARM recognition by different RNA molecules. Outlined residues indicate a 10 -fold or greater loss in activation or binding upon substitution of the indicated amino acid; underlined residues have been demonstrated to make RNA contacts in NMR structures. The functional and structural data for the RBE are from Tan et al. (1993) and Battiste et al. (1996), respectively. The functional data for a representative aptamer selected against the Rev ARM peptide are from Xu and Ellington (1996), and the structural data are from Ye et al. (1999). The structural data for a representative aptamer selected against the Rev protein are from Ye et al. (1996).

and decreases in activation, although not as starkly. It should be noted that the results of experiments with the alanine-scan series of peptides were consistent with those previously carried out with other amino acid substitutions (Table 1); for example, both N7D and N7A have little efect on activation, whereas both R10Y and R10A inhibit activation by about $60 \%$. In addition, it should be recalled that the Rev 1-9 peptide fragment was unable to substantially activate clone 8-4 (Fig. 7) or clones $4 \mathrm{~d}$ and $4 \mathrm{f}$ (data not shown), despite the fact that it contained all three of the most critical arginine residues. Nonetheless, although the aptazymes can clearly recognize individual amino acids, it is still possible that the peptide acts primarily to neutralize charge, because the replacement of any single arginine within the peptide results in a greater loss of activity than the replacement of any of the seven residues that are not arginine.

The specificity of aptazyme 8-4 for the Rev ARM can be compared with other natural or engineered RNA-binding sites for the same peptide. The binding affinities of the RBE for a series of alanine-substituted Rev ARM peptides have previously been determined (Tan et al. 1993), and again provide a map of functional amino acid interactions (Fig. $11 \mathrm{~B}$, residues whose substitution diminished binding 10fold are shown outlined). Similarly, the binding affinities of several peptide variants for a representive anti-Rev ARM peptide aptamer have been determined, and arginine 11 was shown to be critical for binding (Fig. 11B; Xu and Ellington 1996). In addition, the NMR structures of the Rev ARM complexed with either the natural Rev-binding element or with anti-Rev aptamers have been determined (Battiste et al. 1996; Ye et al. 1996, 1999), and contacts between amino acids in the Rev ARM and these RNA elements can be tabulated (Fig. 11B, underlines). The preponderance of contacts with arginine residues is readily apparent for all of these structured RNA molecules, whether catalysts or not. Interestingly, which arginines are important for binding seems to vary between the RNAs. For example, the mutation of either R8 or R9 in the Rev ARM is deleterious to activation of the aptazyme; however, neither mutation strongly affected binding by the RBE and these two arginine residues do not form close contacts with an antipeptide aptamer. Conversely, whereas T1 and N7 are critical for RBE binding, their loss mediates a slight increase and only a minor decrease, respectively, in aptazyme activation. The finding that a Rev ARM-dependent aptazyme interacts with a different set of amino acid residues than other natural or selected Rev ARM-binding domains is consistent with previous findings that a series of anti-Rev ARM peptide aptamers functionally recognize various amino acid residues on the Rev ARM (Xu and Ellington 1996). These results are also consistent with the observation that the same ARM peptide can assume different conformations when bound by different RNA molecules (Battiste et al. 1996; Ye et al. 1999; Smith et al. 2000). As a final note, selections against peptide targets seem to yield fewer interactions than do selections against protein targets; the anti-Rev ARM peptide aptamer and aptazyme 8-4 show only three or four structural or functional contacts, whereas the RBE and anti-Rev protein aptamers show structural or functional contacts throughout their lengths.

\section{Implications for the development of reagents for proteomics}

It has proven possible to select aptazymes that are dependent on the Rev protein for function by initially selecting for aptazymes that are dependent on a peptide derived from the Rev protein, just as antipeptide antibodies have frequently been shown to bind to their cognate proteins (Celada et al. 1978; Paul et al. 1981). These results are also reminiscent of previous studies in which aptamers selected against the Rev ARM peptide were able to specifically bind 
to the Rev protein ( $\mathrm{Xu}$ and Ellington 1996). Indeed, in several instances, antipeptide aptamers have been shown to be active against the proteins from which they were derived (Bianchini et al. 2001; Kimoto et al. 2002). Although the generality of our approach remains to be seen, we anticipate that aptazymes raised against peptides may be generally activated by corresponding proteins.

However, our results also indicate that aptazymes selected to be activated by peptides cannot be easily optimized to be as highly activated by proteins. Despite the fact that an extremely diverse pool was employed during the reselection for protein dependence, little or no increase in protein activation was observed. The allosteric site of aptazyme 8-4 may not be suitable to accommodate the surface or extent of the entire Rev protein. Although it is difficult to optimize aptazyme 8-4 for protein dependence, it is relatively easy to find substitutions that can drastically increase discrimination against the Rev protein. The latter point is further emphasized by the fact that all peptide-dependent variants tested showed at least a fivefold lower activation by the Rev protein than the parental aptazyme, even though this property was not selected for.

Even if greater mutation frequencies would allow access to more protein-dependent aptazymes they might prove difficult to select. Just as the effector-independent ribozyme $\mathrm{JH}-1$ variant arose during the initial selection, a number of effector-independent ribozymes began to arise during the reselection experiments. An aptazyme variant (6b) that had a very high background ligation rate in the absence of peptide was found twice in the selection for Rev ARM peptide dependence, and a similar variant (6d) was found in the selection for protein dependence. The relatively peptideindependent $6 \mathrm{~b}$ is the fastest ribozyme derived from the selection for peptide dependence (save for the JH-1 variant), yet differs from the highly dependent parental aptazyme $8-4$ by only three mutations. Thus, it may be that selections that attempt to alter or optimize the effector dependence of aptazymes will always be in danger of being overrun by effector-independent variants.

Nonetheless, the selections described herein demonstrate the feasibility of obtaining protein-dependent ribozymes via a selection for peptide dependence. This scheme could prove useful for selecting aptazymes against targets that are not otherwise stable or readily available, or for generating aptazymes against particular epitopes. Aptazymes could also be selected against synthetic peptide targets identified by analyses of proteomics databases. The selection methods used for the generation of aptazymes are similar to those that have been used to generate aptamers, and are amenable to automation (Cox et al. 1998; Sooter et al. 2001). Moreover, aptazymes have already been adapted to array analysis (Seetharaman et al. 2001). Thus, the results described in this article may be a first step towards the high-throughput generation of aptazyme chips for proteome analysis.

\section{MATERIALS AND METHODS}

\section{Nucleic acid pools, primers, and substrates}

The L1-N50 pool was generated from a synthetic oligonucleotide (5'-TTCTAATACGACTCACTATAGGACCTCGGCGAAAGC $\left(\mathrm{N}_{50}\right)$ GAGGTTAGGTGCCTCGTGATGTCCAGTCGC) that contained a T7 RNA polymerase promoter (underlined) and a 50-nt random region $\left(\mathrm{N}_{50}\right)$. The pool for reselection experiments was generated from a synthetic oligonucleotide based on the sequence of aptazyme 8-4 (5'-TTCTAATACGACTCACTATAGGACCTCGG CGAAAGCCGGTAACGCCACAAGTCGGAGGGTAAGATCTGA CAGGAACTGGGTGACGGAGGTTAGGTGCCTCGTGATGTCC AGTCGC). The 49 residues in bold correspond to the original random sequence region and upon resynthesis were $70 \%$ wild-type nucleotides and $10 \%$ each non-wild-type nucleotide. Both pools were amplified with the primers $20 . \mathrm{T} 7$ (5'-TTCTAATACGACT CACTATA) and 18.90a (5'-GCGACTGGACATCACGAG). The substrate used during selection was S28A-biotin, a chimeric DNA:RNA oligonucleotide with a biotin at its $5^{\prime}$ end (5'biotin$\left.(\mathrm{dA})_{22} \mathrm{r}(\mathrm{UGCACU})\right)$. Assays were performed with a nonbiotinylated version of this substrate, S28A. The primers 28A.180 $\left(5^{\prime} \mathrm{A}_{22}\right.$ TGTACT) and 36.dB.2 (5' -TTCTAATACGACTCACTATA GGACCTCGGCGAAAGC) were used during ribozyme amplification.

\section{ARM peptides and proteins}

The peptide effector used for selection, sRevn, is the arginine-rich motif of the HIV-1 Rev protein, residues 34-50 (TRQAR RNRRRRWRERQR), with a succinyl group at its $\mathrm{N}$ terminus and an amide at its $\mathrm{C}$ terminus to promote alpha-helicity. The peptide sRevn was purchased from Genemed Synthesis, as were aRev (Acyl-TRQARRNRRRRWRERQR), the aRev ARM fragments (aRev 1-9, aRev 10-17), and the HIV and BIV Tat ARMs. These peptides were purified by reverse-phase HPLC on a C18 column, except for sRevn, for which a C4 column was used. All other ARM peptides were purchased from Bio-Synthesis. The sequences of the various ARMs are shown in Table 1, and were taken from the literature (peptides 1-14; Alizon et al. 1986; Tan and Frankel 1995; Reyes et al. 2001) or were predicted to be arginine-rich motifs based on a sequence alignment of known ARM peptides (peptides 15-16). Rev and Tat peptide concentrations were calculated following the determination of the absorbance of peptide solutions at $280 \mathrm{~nm}$, except for BIV Tat, where concentration was determined based on mass, as it contained no aromatic residues. The W12A Rev ARM also contained no aromatic residues, and its concentration was determined by measurement of the absorbance of the peptide solution at $214 \mathrm{~nm}$ and comparison with a known stock of the wild-type Rev ARM. Bradykinin was obtained from Novabiochem and was used as supplied. The concentrations of all other peptide solutions were determined based on the mass of the peptides.

Constructs for the expression of HIV-1 Rev were obtained from David Rekosh (University of Virginia) and the protocol for Rev expression and purification was adapted from Orsini et al. (1995). In short, Rev was purified using a SP Sepharose (BioRad) column and concentrated with a Centricon 10,000 MW cut-off filter (Millipore). The purity of the protein was confirmed in three ways: (1) 
by SDS-PAGE against a standard obtained from the NIH; (2) by MALDI mass spectral analysis; and (3) by binding assays with the Rev-binding element of HIV-1. NIH standards for HIV proteins were obtained through the AIDS Research and Reference Reagent Program, Division of AIDS, NIAID, NIH: HIV-1 Rev (Wild Type) from David Rekosh, Marie-Louise Hammarskjöld, and Michael Orsini. CYT-18 protein was a gift from the Lambowitz lab (University of Texas, Austin; Mohr et al. 1992), bovine serum albumin was purchased from New England Biolabs, and lysozyme was purchased from Sigma.

\section{Selection scheme}

Each round of the original and doped sequence selections, except the first, consisted of a negative selection in the absence of a peptide or protein effector and a positive selection in the presence of an effector. The first round did not include a negative selection. Pool RNA $\left(5 \mu \mathrm{M}\right.$ final concentration; 2.0 nmoles $\left[\sim 10^{15}\right.$ unique sequences] in the first round) was denatured $\left(70^{\circ} \mathrm{C}\right.$ for $3 \mathrm{~min}$, cooled to room temperature) in water in the presence of a twofold excess of 18.90a. Ligation buffer ( $50 \mathrm{mM}$ Tris at $\mathrm{pH} 7.5,100 \mathrm{mM}$ $\mathrm{KCl}, 10 \mathrm{mM} \mathrm{MgCl}_{2}$ final concentration), water, and substrate S28A-biotin (typically $10 \mu \mathrm{M}$ ) were added and the reaction was incubated at $25^{\circ} \mathrm{C}$ for varying periods of time (Tables 2, 3). Streptavidin-agarose beads were added to the reaction to remove unligated substrates and ligated ribozymes. The beads were incubated with the reaction mixture at room temperature for $30 \mathrm{~min}$, and were then removed by filtration. The supernatant was replenished with 18.90a $(5 \mu \mathrm{M})$ and S28A-biotin $(10 \mu \mathrm{M})$, and the positive selection was initiated by the addition of peptide or protein effector to a final concentration of $10 \mu \mathrm{M}$. The Rev ARM peptide was stored in distilled water, and its addition did not affect the final salt concentration. However, the Rev protein was suspended in 50 $\mathrm{mM}$ Tris ( $\mathrm{pH} 7.5$ ), $500 \mathrm{mM} \mathrm{NaCl}$, and its addition resulted in a final $\mathrm{NaCl}$ concentration of $33 \mathrm{mM}$. Following incubation at $25^{\circ} \mathrm{C}$ for varying periods of time (Tables 2, 3), ligation reactions were quenched by the addition of EDTA to a final concentration of 50 $\mathrm{mM}$. Active variants were isolated by affinity capture on streptavidin-agarose beads, converted to DNA by reverse transcription

TABLE 2. Incubation times for the initial selection for Rev ARM dependence

\begin{tabular}{ccc}
\hline Round & $(-)$ Incubation time & $(+)$ Incubation time \\
\hline 1 & - & $16 \mathrm{~h}$ \\
2 & $24 \mathrm{~h}$ & $16 \mathrm{~h}$ \\
3 & $24 \mathrm{~h}$ & $5 \mathrm{~h}$ \\
4 & $24 \mathrm{~h}$ & $30 \mathrm{~min}$ \\
5 & $48 \mathrm{~h}$ & $5 \mathrm{~min}$ \\
6 & $95 \mathrm{~h}$ & $5 \mathrm{~min}$ \\
7 & $95 \mathrm{~h}$ & $1 \mathrm{~min}$ \\
8 & $95 \mathrm{~h}$ & $30 \mathrm{sec}$ \\
9 & $94 \mathrm{~h}$ & $30 \mathrm{sec}$ \\
\hline
\end{tabular}

The amount of time allowed for negative and positive selection are shown for each round. Selection conditions were as presented in the Materials and Methods section, with the exception that $25 \mu \mathrm{M}$ substrate (instead of $10 \mu \mathrm{M}$ ) was added during the (-) selection of Round 9.
TABLE 3. Incubation times for the reselection of Rev ARM and Rev protein dependence

\begin{tabular}{lcc}
\hline Round & $(-)$ Incubation time & $(+)$ Incubation time \\
\hline Doped Rev ARM reselection & \\
1 & - & $16 \mathrm{~h}$ \\
2 & $25 \mathrm{~h}$ & $12 \mathrm{~h}$ \\
3 & $235 \mathrm{~h}$ & $3 \mathrm{~h}$ \\
4 & $115 \mathrm{~h}$ & $5 \mathrm{~min}$ \\
5 & $113 \mathrm{~h}$ & $5 \mathrm{~min}$ \\
6 & $44 \mathrm{~h}$ & $5 \mathrm{sec}$ \\
Doped Rev Protein reselection & \\
1 & - & $14 \mathrm{~h}$ \\
2 & $17 \mathrm{~h}$ & $3 \mathrm{~h}$ \\
3 & $90 \mathrm{~h}$ & $1 \mathrm{~h}$ \\
4 & $120 \mathrm{~h}$ & $1.5 \mathrm{~h}$ \\
5 & $44 \mathrm{~h}$ & $5 \mathrm{~min}$ \\
6 & $155 \mathrm{~h}$ & $5 \mathrm{~min}$ \\
\hline
\end{tabular}

The amount of time allowed for negative and positive selection are shown for each round. Selection conditions were as presented in the Materials and Methods section, with the exception that only $5 \mu \mathrm{M} \mathrm{S28A}$ substrate was used for the (+) selection in Rounds 5 and 6 of the Rev ARM reselection and in Rounds 4, 5, and 6 of the Rev protein reselection. Additionally, $20 \mu \mathrm{M} \mathrm{S28A}$ substrate was used for the (-) selection in Round 6 of the Rev ARM reselection.

with the 18.90a primer (Superscript II, Invitrogen), and selectively amplified in a polymerase chain reaction with the primers $28 \mathrm{~A} .180$ and 18.90a. DNA templates for transcription were generated in a second polymerase chain reaction with the primers $36 . \mathrm{dB} .2$ and 18.90a. RNA pools for additional rounds of selection were generated by in vitro transcription with T7 RNA polymerase (Ampliscribe Kit, Epicentre). RNA was gel purified on an $8 \%$ denaturing polyacrylamide gel prior to use.

\section{Ligation assays}

Ligation assays were performed with RNA transcribed in the presence of a small amount (typically $2.5 \mu \mathrm{M}, \sim 10 \mu \mathrm{Ci}$ ) of $\alpha-{ }^{32} \mathrm{P}$ UTP (Perkin Elmer). Labeled RNA (10 pmoles) and 18.90a (20 pmoles) were thermally equilibrated $\left(70^{\circ} \mathrm{C}\right.$ for $3 \mathrm{~min}$, cool to room temperature) in $5 \mu \mathrm{L}$ of water. Ligation buffer $(50 \mathrm{mM}$ Tris at $\mathrm{pH} 7.5$, $100 \mathrm{mM} \mathrm{KCl}, 10 \mathrm{mM} \mathrm{MgCl}_{2}$ final concentration) and peptide effector (where applicable, 150 pmoles) were added and the mixture was incubated at room temperature for $5 \mathrm{~min}$. As with the selection experiments, addition of Rev protein to a ligation assay resulted in a final $\mathrm{NaCl}$ concentration of $33 \mathrm{mM}$. Other protein effectors were also dissolved in buffers of varying ionic compositions, and although their addition to ligation assays resulted in changes in final ionic strengths, none were as large as that for the Rev protein buffer. Ligation reactions were initiated by the addition of S28A (20 pmoles) in a total reaction volume of $15 \mu \mathrm{L}$. Aliquots $(4 \mu \mathrm{L})$ were removed at various time points and quenched in Super Stop Dye $(46 \mu \mathrm{L} ; 100 \mathrm{mM}$ EDTA, $80 \%$ formamide, $0.05 \%$ bromophenol blue, saturated with urea and SDS). Reaction aliquots were heat denatured $\left(70^{\circ} \mathrm{C}\right.$ for $\left.3 \mathrm{~min}\right)$ and ligation products were separated from unligated ribozymes on an $8 \%$ denaturing polyacrylamide gel ( $1 \times \mathrm{TBE}, 7 \mathrm{M}$ urea, $0.01 \% \mathrm{SDS})$. Radioactive bands were visualized and quantitated using a Phos- 
phorImager (Molecular Dynamics), and reaction rates were determined for the initial log-linear portion of the reaction.

Mock rounds of selection were carried out with variant 8-2 and other apparently inactive variants to determine if ligation products could be observed. Mock rounds were performed as above (see Selection Scheme) using ${ }^{32} \mathrm{P}$ body-labeled RNA and both the biotinylated and nonbiotinylated versions of the S28A substrate. An aliquot from the reaction was removed and quenched after each step of the selection procedure, with the final point being removed after the reverse transcription. Analysis was carried out on an $8 \%$ denaturing polyacrylamide gel, as described above.

\section{ACKNOWLEDGMENTS}

The authors thank Amy Yan for preparation of the HIV-1 Rev protein and Matthew Levy for peptide purification. This work was supported by NIH/NIGMS Grant R01 GM61789-02 and NASA Scripps Astrobiology Grant 5-97458/NCC2-1055.

The publication costs of this article were defrayed in part by payment of page charges. This article must therefore be hereby marked "advertisement" in accordance with 18 USC section 1734 solely to indicate this fact.

Received May 19, 2003; accepted September 22, 2003.

\section{REFERENCES}

Alizon, M., Wain-Hobson, S., Montagnier, L., and Sonigo, P. 1986. Genetic variability of the AIDS virus: Nucleotide sequence analysis of two isolates from African patients. Cell 46: 63-74.

Battiste, J.L., Mao, H., Rao, N.S., Tan, R., Muhandiram, D.R., Kay, L.E., Frankel, A.D., and Williamson, J.R. 1996. $\alpha$-helix-RNA major groove recognition in an HIV-1 rev peptide-RRE RNA complex. Science 273: 1547-1551.

Bianchini, M., Radrizzani, M., Brocardo, M.G., Reyes, G.B., Gonzalez Solveyra, C., and Santa-Coloma, T.A. 2001. Specific oligobodies against ERK-2 that recognize both the native and the denatured state of the protein. J. Immunol. Methods 252: 191-197.

Celada, F., Fowler, A.V., and Zabin, I. 1978. Probes of $\beta$-galactosidase structure with antibodies. Reaction of anti-peptide antibodies against native enzyme. Biochemistry 17: 5156-5160.

Cox, J.C., Rudolph, P., and Ellington, A.D. 1998. Automated RNA selection. Biotechnol. Prog. 14: 845-850.

Feng, S. and Holland, E.C. 1988. HIV-1 tat trans-activation requires the loop sequence within tar. Nature 334: 165-167.

Frankel, A.D. 2000. Fitting peptides into the RNA world. Curr. Opin. Struct. Biol. 10: 332-340.

Frauendorf, C. and Jaschke, A. 2001. Detection of small organic analytes by fluorescing molecular switches. Bioorg. Med. Chem. 9: 2521-2524.

Gosser, Y., Hermann, T., Majumdar, A., Hu, W., Frederick, R., Jiang, F., Xu, W., and Patel, D.J. 2001. Peptide-triggered conformational switch in HIV-1 RRE RNA complexes. Nat. Struct. Biol. 8: 146150.

Green, R., Ellington, A.D., and Szostak, J.W. 1990. In vitro genetic analysis of the Tetrahymena self-splicing intron. Nature 347: 406408.

Harada, K., Martin, S.S., Tan, R., and Frankel, A.D. 1997. Molding a peptide into an RNA site by in vivo peptide evolution. Proc. Natl. Acad. Sci. 94: 11887-11892.

Herschlag, D., Khosla, M., Tsuchihashi, Z., and Karpel, R.L. 1994. An RNA chaperone activity of non-specific RNA binding proteins in hammerhead ribozyme catalysis. EMBO J. 13: 2913-2924.

Huang, Z.S. and Wu, H.N. 1998. Identification and characterization of the RNA chaperone activity of hepatitis delta antigen peptides. $J$. Biol. Chem. 273: 26455-26461.

Jiang, F., Gorin, A., Hu, W., Majumdar, A., Baskerville, S., Xu, W., Ellington, A., and Patel, D.J. 1999. Anchoring an extended HTLV-1 Rex peptide within an RNA major groove containing junctional base triples. Structure Fold. Des. 7: 1461-1472.

Kimoto, M., Shirouzu, M., Mizutani, S., Koide, H., Kaziro, Y., Hirao, I., and Yokoyama, S. 2002. Anti-(Raf-1) RNA aptamers that inhibit Ras-induced Raf-1 activation. Eur. J. Biochem. 269: 697-704.

Kjems, J., Calnan, B.J., Frankel, A.D., and Sharp, P.A. 1992. Specific binding of a basic peptide from HIV-1 Rev. EMBO J. 11:11191129.

Koizumi, M., Soukup, G.A., Kerr, J.N., and Breaker, R.R. 1999. Allosteric selection of ribozymes that respond to the second messengers cGMP and cAMP. Nat. Struct. Biol. 6: 1062-1071.

Lazinski, D., Grzadzielska, E., and Das, A. 1989. Sequence-specific recognition of RNA hairpins by bacteriophage antiterminators requires a conserved arginine-rich motif. Cell 59: 207-218.

Marshall, K.A. and Ellington, A.D. 1999. Molecular parasites that evolve longer genomes. J. Mol. Evol. 49: 656-663.

Mathews, D.H., Sabina, J., Zuker, M., and Turner, D.H. 1999. Expanded sequence dependence of thermodynamic parameters improves prediction of RNA secondary structure. J. Mol. Biol. 288: 911-940.

Mohr, G., Zhang, A., Gianelos, J.A., Belfort, M., and Lambowitz, A.M. 1992. The neurospora CYT-18 protein suppresses defects in the phage $\mathrm{T} 4 \mathrm{td}$ intron by stabilizing the catalytically active structure of the intron core. Cell 69: 483-494.

Olsen, H.S., Nelbock, P., Cochrane, A.W., and Rosen, C.A. 1990. Secondary structure is the major determinant for interaction of HIV rev protein with RNA. Science 247: 845-848.

Orsini, M.J., Thakur, A.N., Andrews, W.W., Hammarskjold, M.L., and Rekosh, D. 1995. Expression and purification of the HIV type 1 Rev protein produced in Escherichia coli and its use in the generation of monoclonal antibodies. AIDS Res. Hum. Retroviruses 11: 945-953.

Patel, D.J. 1999. Adaptive recognition in RNA complexes with peptides and protein modules. Curr. Opin. Struct. Biol. 9: 74-87.

Paul, D., Flouret, G., Tomita, J.T., Ranney, K., Schenck, J., and Anderson, B. 1981. Preparation and specificities of antisera to the aminoterminal sequence of the carcinoembryonic antigen. Cancer Res. 41: 2315-2321.

Peterson, R.D. and Feigon, J. 1996. Structural change in Rev responsive element RNA of HIV-1 on binding Rev peptide. J. Mol. Biol. 264: 863-877.

Reyes, C.M., Nifosi, R., Frankel, A.D., and Kollman, P.A. 2001. Molecular dynamics and binding specificity analysis of the bovine immunodeficiency virus BIV Tat-TAR complex. Biophys. J. 80: $2833-2842$.

Robertson, M.P. and Ellington, A.D. 1999. In vitro selection of an allosteric ribozyme that transduces analytes to amplicons. Nat. Biotechnol. 17: 62-66.

. 2001. In vitro selection of nucleoprotein enzymes. Nat. Biotechnol. 19: 650-655.

Robertson, M.P., Hesselberth, J.R., and Ellington, A.D. 2001. Optimization and optimality of a short ribozyme ligase that joins nonWatson-Crick base pairings. RNA 7: 513-523.

Rogers, J., Chang, A.H., von Ahsen, U., Schroeder, R., and Davies, J. 1996. Inhibition of the self-cleavage reaction of the human hepatitis delta virus ribozyme by antibiotics. J. Mol. Biol. 259: 916-925.

Seetharaman, S., Zivarts, M., Sudarsan, N., and Breaker, R.R. 2001. Immobilized RNA switches for the analysis of complex chemical and biological mixtures. Nat. Biotechnol. 19: 336-341.

Smith, C.A., Calabro, V., and Frankel, A.D. 2000. An RNA-binding chameleon. Mol. Cell 6: 1067-1076.

Sooter, L.J., Riedel, T., Davidson, E.A., Levy, M., Cox, J.C., and Ellington, A.D. 2001. Toward automated nucleic acid enzyme selection. Biol. Chem. 382: 1327-1334.

Tan, R. and Frankel, A.D. 1995. Structural variety of arginine-rich 
RNA-binding peptides. Proc. Natl. Acad. Sci. 92: 5282-5286.

Tan, R., Chen, L., Buettner, J.A., Hudson, D., and Frankel, A.D. 1993. RNA recognition by an isolated $\alpha$ helix. Cell 73: 1031-1040.

Tang, J. and Breaker, R.R. 1997. Rational design of allosteric ribozymes. Chem. Biol. 4: 453-459.

Wang, D.Y., Lai, B.H., and Sen, D. 2002. A general strategy for effector-mediated control of RNA-cleaving ribozymes and DNA enzymes. J. Mol. Biol. 318: 33-43.

Weeks, K.M., Ampe, C., Schultz, S.C., Steitz, T.A., and Crothers, D.M. 1990. Fragments of the HIV-1 Tat protein specifically bind TAR RNA. Science 249: 1281-1285.
Xu, W. and Ellington, A.D. 1996. Anti-peptide aptamers recognize amino acid sequence and bind a protein epitope. Proc. Natl. Acad. Sci. 93: 7475-7480.

Ye, X., Gorin, A., Ellington, A.D., and Patel, D.J. 1996. Deep penetration of an $\alpha$-helix into a widened RNA major groove in the HIV-1 rev peptide-RNA aptamer complex. Nat. Struct. Biol. 3: 10261033.

Ye, X., Gorin, A., Frederick, R., Hu, W., Majumdar, A., Xu, W., McLendon, G., Ellington, A., and Patel, D.J. 1999. RNA architecture dictates the conformations of a bound peptide. Chem. Biol. 6: 657-669. 

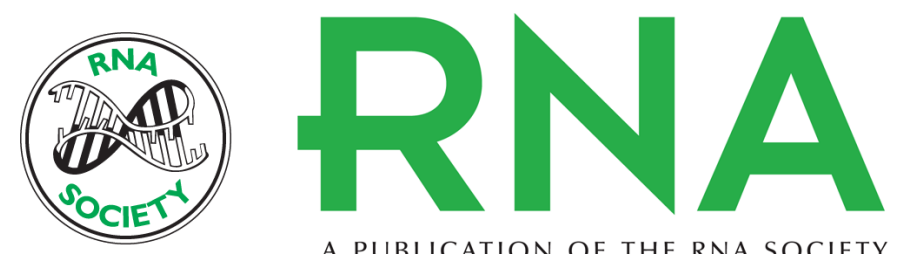

A PUBLICATION OF THE RNA SOCIETY

\title{
In vitro selection of ribozymes dependent on peptides for activity
}

\author{
MICHAEL P. ROBERTSON, SCOTT M. KNUDSEN and ANDREW D. ELLINGTON
}

RNA 2004 10: 114-127

References This article cites 42 articles, 9 of which can be accessed free at:

http://rnajournal.cshlp.org/content/10/1/114.full.html\#ref-list-1

License

Email Alerting Receive free email alerts when new articles cite this article - sign up in the box at the Service top right corner of the article or click here. 